Jurnal Unifikasi, ISSN 2354-5976

Vol. 3 No. 2 Juli 2016

\title{
PERLINDUNGAN HUKUM TERHADAP KONSUMEN DALAM TRANSAKSI JUAL BELI SECARA ELEKTRONIK DI INDONESIA
}

\author{
Suwari Akhmaddhian \\ Fakultas Hukum Universitas Kuningan, suwari.uniku@gmail.com \\ Asri Agustiwi \\ Fakultas Hukum Universitas Surakarta, asri.tiwi@gmail.com
}

\begin{abstract}
Legal protection of the consumer in the sale and purchase transactions electronically in Indonesia is very important for the economic development of society. The purpose of this study was to determine the validity of the Purchase Agreement How Electronics in Indonesia and How Legal Protection Against Consumer Purchase of Electronic Transactions in Indonesia. The research method is normative, data collection is done through literature. Results of the study are: First, the Sale and Purchase Agreement validity Electronics in Indonesia under Article 47 and Article 48 of Government Regulation No. 82 Year 2012 on the Implementation System and Electronic Transactions; Second, the legal protection for the people contained in article 46 of Law No. 11 Year 2008 on Information and Electronic Transactions and Article 62 of Law No. 8 of 1999 on Consumer Protection. Legal protection of the consumer in the sale and purchase transactions electronically in Indonesia are strictly regulated both in the criminal and civil.
\end{abstract}

Keywords: consumer, legal protection, sale and purchase transactions electronically.

\begin{abstract}
Abstrak
Perlindungan hukum terhadap konsumen dalam transaksi jual beli secara elektronik di Indonesia adalah hal yang sangat penting untuk berkembangnya ekonomi masyarakat. Tujuan penelitian ini adalah untuk mengetahui Bagaimana KeabsahanPerjanjian Jual Beli Elektronik di Indonesia dan Bagaimanakah Perlindungan Hukum Terhadap Konsumen Dalam Transaksi Jual Beli Secara Elektronik di Indonesia. Metode penelitian adalah yuridis normatif, pengumpulan data dilakukan melalui studi pustaka. Hasil penelitian yaitu: Pertama, KeabsahanPerjanjian Jual Beli Elektronik di Indonesia diatur Pasal 47 dan Pasal 48 Peraturan Pemerintah Nomor 82 Tahun 2012 tentang Penyelenggaraan Sistem dan Transaksi Elektronik; Kedua, Perlindungan hukum bagi masyarakat terdapat dalam Pasal 46 Undang-Undang No. 11 Tahun 2008 tentang Informasi dan Transaksi Elektronik dan Pasal 62 Undang-Undang Nomor 8 Tahun 1999 tentang Perlindungan Konsumen. Perlindungan hukum terhadap konsumen dalam transaksi jual beli secara elektronik di Indonesia diatur secara tegas baik dari sisi pidana maupun perdata.
\end{abstract}

Kata kunci : konsumen, perlindungan hukum, transaksi jual beli elektronik. 


\section{A. Pendahuluan}

Perkembangan teknologi informasi pada saat ini di Indonesia kemajuanya sangat pesat dan semuanyatelah menjamur dalam kehidupan yang mengunakan kecanggihan teknologi. Di dalam UndangUndang Dasar (UUD) 1945 Pasal 28F disebutkan bahwa "Setiap orang berhak untuk berkomunikasi dan memperoleh informasi untuk mengembangkan pribadi dan lingkungan sosialnya, serta berhak untuk mencari, memperoleh, memiliki, menyimpan, memgelolah, dan menyampaikan informasi dengan menggunakan segala jenis saluran yang tersedia". Artinya negara memiliki kewajiban untuk melindungi, memenuhi dan menghormati hak atas informasi itu. Dengan demikian maka negara mempunyai peran dalam melindungi warga negaranya dari manfaat negatif teknologi informasi khususnya transaksi elektronik. Perkembangan teknologi yang sangat pesat membawa kemajuan pada hampir seluruh aspek kehidupan manusia ${ }^{1}$. Salah satu perkembangan teknologi yang di kenal oleh masyarakat luas adalah internet, yaitu teknologi yang memberikan kemudahan komunikasi secara global dan memungkinkan manusia memperoleh serta saling bertukar informasi dengan cepat. Pada awalnya internet hanya dapat digunakan sebagai media pertukaran informasi di lingkungan pendidikan (Perguruan Tinggi) dan lembaga penelitian ${ }^{2}$.

\footnotetext{
1 Man Suparman Sastrawidjaja, Perjanjian Baku Dalam Aktivitas Dunia Maya, Cyberlaw: Suatu Pengantar, Cetakan I, Jakarta : Elips II, 2002, hlm.14

2 Budi Rahardjo, Peraturan dan Pengaturan Cyberspace di Indonesia, tersedia di
}

Setelah internet terbuka bagi masyarakat luas, internet mulai digunakan juga untuk kepentingan perdagangan. Setidaknya ada dua hal yang mendorong kegiatan perdagangan dalam kaitannya dengan kemajuan teknologi yaitu meningkatnya permintaan atas produkproduk teknologi itu sendiri dan kemudahan untuk melakukan transaksi perdagangan ${ }^{3}$. Selain itu, Perkembangan teknologi informasi trersebut sangat pesat dan telah membawa banyak perubahan. Perubahan pola kehidupan tersebut terjadi hampir di semua bidang, baik sosial, budaya, ekonomi, maupun bidang lainnya. Perubahan tersebut antara lain dengan berkembangnya penggunaan teknologi internet (telematika) yang merupakan salah satu bagian dariperkembangan teknologi informasi.

Salah satu perubahan yang sangat besar akibat berkembangnya teknologi informasi adalah dalam bidang ekonomi. Perkembangan teknologi informasi secara signifikan telah mengubah sistem ekonomi konvensional menjadi sistem ekonomi digital. Sistem digital ini memungkinkan dunia usaha melakukan suatu transaksi dengan menggunakan media elektronik yang lebih menawarkan kemudahan, kecepatan, danefisiensi. Saat ini banyak dijumpai transaksi-transaksi perdagangan modern yang menggunakan teknologi sebagai medianya atau yang lazim disebut transaksi elektronik atau perdagangan elektronik atau electronic commerce (e-commerce). Sebuah

<https://behard.files.wordpress.com/2011/01/draftbuku-cyberlaw.pdf>,diakses pada 6 Mei 2016 pukul 14.00 WIB.

3 Asril Sitompul, Hukum Internet (Pengenal Mengenai Masalah Hukum di Cyberspace), Cetakan II, Bandung : PT. Citra Aditya Bakti, 2004, hlm. 4. 
tantangan perkembangan jaman yang perlu mendapat perhatian serius jika tidak ingin "mendapatkan masalah" dikarenakan ketidaksiapan Indonesia dalam berbagai aspek (utamanya aspek hukum) untuk mengantisipasi segala kemungkinan yang terjadi berkaitan dengan sistem perdagangan elektronik ini ${ }^{4}$.

Oleh karena itu, tidak mengherankan, bukan saja di negara-negara maju, di Indonesia-pun pemanfaatan internet yang berbasis e-commerce, e-business, dan lain sebagainya berkembang dengan cepat. Pada saat ini dunia perbankan nasional telah banyak yang memanfaatkan fasilitas ini untuk memberikan kemudahan pelayanan dalam melakukan kegiatan perbankan bagi nasabahnya dengan menggunakan $e$ bankingatau internet banking.Demikian juga di Indonesia. Penggunaan internet di Indonesia sebenarnya baru dimulai pada tahun 1993 dan pada awalnya hanya terbatas untuk hiburan, namun saat ini penggunaan internet di Indonesia juga telah mencakup penggunaan untuk kepentingan perdagangan.

Melihat potensi dan perkembangan $e$ commerce bagi perekonomian Indonesia,Jokowi bersama 4 (empat) menteri mengajak 5 (lima) bosperusahaan $e$ commerce dalam negeri, yakni Nadiem Makarim (CEO Go Jek), William Tanuwijaya (Pendiri Tokopedia), Emirsyah Satar (Chairman MatahariMall.com), Ferry Unardi (Pendiri Traveloka), dan Andrew

\footnotetext{
4 Emilda Kuspraningrum, Keabsahan Kontrak Elektronik Dalam UU ITE Ditinjau Dari Pasal 1320 KUHPerdata dan UNCITRAL Model Law On Electronic Commerce, Risalah HUKUM Fakultas Hukum Unmul Vol. 7, No. 2, Desember 2011, hlm. $182-194$.
}

Darwis (Pendiri Kaskus). Sementara 5 (lima) kapitalis ventura terbesar di dunia ini, di antaranya pemodal besar dari Amerika Serikat, yaitu Sequoia Capital dan Queen of The Net Mary Meeker. Sequoia merupakan perusahaan sukses yang dikenal dengan banyak portofolio investasi, seperti Google, Cisco, Apple, YouTube, WhatsApp, Nvidia, Dropbox, PayPal, Yahoo, Oracle, LinkedIn, Airbnb, dan Square. "Kita pertemukan 5 kapital ventura internasional dan 5 perusahaan e-commerce yang sukses mencatat nilai kapitalisasi besar dan berpeluang menjadi perusahaan bertaraf internasional ${ }^{5}$.

Dapat kita lihat pula di Indonesia untuk yang besar, bisa merujuk pada semakin besarnya toko online seperti Bhinneka, Lazada, Olx, Berniaga, Bejubel, Kaskus FJB, dan masih banyak sekali. Sekarang orang juga banyak yang menggunakan Facebook dan Twitter untuk mempromosikan produk mereka, dan hasilnya relatif efektif meningkatkan penjualan. Kegiatan e-commerce tidak hanya berupa transaksi jual beli di toko online, melainkan juga semua transaksi keuangan di bank yang memanfaatkan internet sebagai medianya. Searah dengan perubahan masyarakat yang sedemikian komplek dalam berbagai dimensinya, aktivitas e-commerce membawa implikasi di bidanghukum, yaitu terkait tentang:otentikasi subyek hukum yang membuat transaksi melalui internet;

\footnotetext{
5 Jokowi Boyong 5 Bos Perusahaan e-Commerce RI ke AS, tersedia di <http://bisnis.liputan6.com/read/2347628/jokowiboyong-5-bos-perusahaan-e-commerce-ri-keas>diakses pada 6 Mei 2016 pukul 14.00 WIB.
} 
kekuatan mengikat secara hukum ; obyek transaksi yang diperjualbelikan;mekanisme peralihan hak; hubungan hukum dan pertanggungjawaban para pihak yang terlibat dalam transaksi; legalitas dokumen catatan elektronik serta tanda tangan digital sebagai alat bukti;mekanisme penyelesaian sengketa; pilihan hukum dan forum peradilan yang berwenang dalam penyelesaian sengketa $e$-commerce.

Problematika-problematika secara tidak langsung, menunjukkan bahwa telah terjadi pergeseran dari model perdagangan konvensional menjadi sistem perdagangan/transaksi elektronik. Menurut hemat penulis, problematika tersebut muncul karena suatu sebab mendasar yaitu persoalan keabsahan dari sistem transaksi tersebut. Tulisan ini mengkaji permasalahan utama, yaitu tentang bagaimana keabsahan transaksi elektronik itu sendiri dan bagaimana perlindungan hukum bagi konsumen (pembeli) dari transaksi elektronik tersebut. (Dalam bahasa yang umum sering disebut korban dari jual beli on line).

\section{B. Rumusan Masalah}

Berdasarkan latar belakang tersebut diatas, maka rumusan masalah yang akan dibahas dalam makalah ini adalah sebagai berikut :

1. Bagaimana KeabsahanPerjanjian Jual Beli Elektronik di Indonesia?

2. Bagaimanakah Perlindungan Hukum Terhadap Konseumen Dalam Transaksi Jual Beli Secara Elektronik di Indonesia?

\section{Pembahasan}

\section{Keabsahan Perjanjian Jual Beli Secara Elektronik di Indonesia.}

Keabsahan adalah keabsahan perjanjian perdagangan atau kontrak perdagangan yang dibuat melalui sistem elektronik. Sudah menjadi kebiasaan jika setiap kesepakatankesepakatan transaksi perdagangan selalu dituangkan dalam sebuah perjanjian atau kontrak. Mengacu kepada teori perdata pada umumnya, sebuah transaksi adalah perbuatan hukum yang melibatkan dua belah pihak yang saling membutuhkan dalam hal yang memiliki nilai ekonomis tertentu, dan biasanya direalisasikan melalui sebuah perikatan yang disebut dengan sebuah istilah kontrak $^{6}$, karena kontrak sendiri berfungsi untuk mengamankan sebuah transaksi ${ }^{7}$.

Sebuah kontrak perdagangan dianggap sah secara hukum jika memenuhi persyaratan secara subyektif dan obyektif, jika salah satu syarat tidak dapat dipenuhi maka kontrak perdagangan tersebut dapat dimintakan pembatalan (syarat subyektif tidak terpenuhi) atau dapat batal demi hukum (syarat obyektif tidak terpenuhi). Secara yuridis, di Indonesia, syarat-syarat sahnya sebuah perjanjian tertuang dalam Pasal 1320 Kitab Undang-undang Hukum

\footnotetext{
${ }^{6}$ Hasanuddin Rahman, Contract Drafting Seri Ketrampilan Merancang Kontrak Bisnis, Bandung : Citra Aditya Bakti, 2003, hlm. 2.

7 Peter Mahmud Marzuki, Kontrak Bisnis Internasional, Bahan Kuliah Magister Hukum Universitas Airlangga, Surabaya, 2001, pada Emilda Kuspraningrum, Keabsahan Kontrak Elektronik Dalam UU ITE Ditinjau Dari Pasal 1320 KUHPerdata dan UNCITRAL Model Law On Electronic Commerce, Risalah HUKUM Fakultas Hukum Unmul Vol. 7, No. 2, Desember 2011, hlm. $182-194$.
} 
Perdata (KUHPerdata), dimana pasal tersebut mensyaratkan 4 hal agar perjanjian dianggap sah secara hukum yaitu: 1) adanya kesepakatan dari para pihak; 2) kecakapan melakukan perbuatan hukum; 3) adanya sebab yang halal; dan 4) adanya objek tertentu. Dua syarat pertama dikategorikan sebagai syarat subyektif dan dua syarat terakhir dikategorikan sebagai syarat obyektif.

Implementasi dari teorisasi dan ketentuan KUHPerdata tersebut di atas, akan lebih mudah mendeteksi adanya ketidakterpenuhan persyaratan pada sistem perjanjian atau kontrak perdagangan yang dibuat secara konvensional dibandingkan mendeteksi tidak dipenuhinya persyaratan pada perjanjian atau kontrak elektronik. Hal ini dikarenakan dalam proses pembuatan kontrak perdagangan konvensional para pihak dimungkinkan sudah saling mengenal, saling bertatap muka atau setidaknya sudah tahu sama tahu kecakapan hukum masingmasing pihak. Hal ini berbeda dengan proses pembuatan kontrak perdagangan secara elektronik, dalam hal ini para pihak sangat dimungkinkan tidak bertemu atau bahkan tidak mengenal satu sama lain. Hal ini mempersulit pendeteksian tidak dipenuhinya syarat-syarat sahnya suatu kontrak. Siapa yang bisa menjamin bahwa dalam sebuah kontrak elektronik para pihak telah cakap hukum untuk membuat kontrak?, lantas bagaimana pula jika sebuah kontrak yang telah dibuat ternyata batal demi hukum di kemudian hari dikarenakan obyek yang diperdagangkan ternyata diperbolehkan di negara penjual tapi tidak diperbolehkan di negara pembeli?. Hal-hal semacam itu tentunya harus diantisipasi agar tidak merugikan para pihak yang terlibat dalam transaksi perdagangan dengan sistem elektronik.

Pada dasarnya, seiring dan sejalan dengan pesatnya perkembangan perdagangan elektonik ini, Perserikatan Bangsa-Bangsa (PBB) merespon dengan membentuk UNCITRAL (United Nations Comission on Internasioanal Trade Law) sebuah lembaga yang diberi tugas mengembangkan hukum perdagangan internasional $^{8}$. Selanjutnya pada tahun 1996 dirumuskan sebuah aturan hukum yang cukup penting yaitu UNCITRAL Model Law on Electronic Commerce. Untuk melengkapi Model Law on Electronic Commerce, UNCITRAL juga memiliki sebuah aturan penting di bidang hukum kontrak internasional khususnya kontrak yang menggunakan elektronik (e-contract) dalam sebuah konvensi yang disebut Convention on the Use of Electronic Communications in International Contracting, yang tujuan utamanya adalah menghilangkan ganjalan atau rintangan yang mungkin timbul sehubungan dengan penggunaan komunikasi secara elektronik, dalam kontrak internasional, juga bertujuan diharapkan akan menciptakan kepastian hukum di kalangan dunia usaha.

Pihak-pihak dalam Transaksi Jual Beli melalui Internet Pada transaksi jual beli secara elektronik, sama halnya dengan transaksi jual beli biasa yang dilakukan di dunia nyata, walaupun dalam jual beli secara elektronik ini pihak-pihaknya tidak bertemu secara langsung satu sama lain, tetapi

8 Huala Adolf, Dasar-Dasar Hukum Kontrak Internasional, Bandung : Refika Aditama, 2007, hal. 42. 
berhubungan melalui internet. Dalam transaksi jual beli melalui internet, pihakpihak yang terkait antara lain:

a. Penjual atau pengusaha yang menawarkan sebuah produk melalui internet sebagai pelaku usaha;

b. Pembeli atau konsumen, yaitu setiap orang yang tidak dilarang oleh undang-undang, yang menerima penawaran dari penjual atau pelaku usaha dan berkeinginan untuk melakukan transaksi jual beli produk yang ditawarkan oleh penjual/pelaku usaha;

c. Bank sebagai pihak penyalur dana dari pembeli atau konsumen kepada penjual, karena pada transaksi jual beli secara elektronik, penjual dan pembeli tidak berhadapan langsung, sebab mereka berada pada lokasi yang berbeda sehingga pembayaran dapat dilakukan melalui perantara, dalam hal ini adalah bank;

d. Provider sebagai penyedia jasa layanan akses internet.

Pelaksanaan transaksi jual beli melalui internet ini dilakukan tanpa ada tatap muka antara para pihaknya, sehingga perjanjian jual beli yang terjadi diantara para pihak pun dilakukan secara elektronik pula, baik melalui e-mail atau cara lainnya. Transaksi jual beli yang dilakukan melalui internet tidak mungkin terhenti, bahkan setiap hari selalu ditemukan teknologi terbaru dalam dunia internet, sementara perlindungan dan kepastian hukum bagi para pengguna internet tersebut tidak mencukupi, dengan demikian harus diupayakan untuk tetap mencapai keseimbangan hukum dalam kondisi termaksud. Hubungan hukum yang terjadi dalam transaksi jual beli secara elektronik tidak hanya tejadi antara pengusaha dengan konsumen saja, tetapi juga terjadi antara pihak-pihak dibawah ini:

a. Business to Business, merupakan transaksi yang terjadi antar perusahaan dalam hal ini, baik pembeli maupun penjual adalah sebuah perusahaan dan bukan perorangan. Biasanya transaksi ini dilakukan karena mereka telah saling mengetahui satu sama lain dan transaksi jual beli tersebut dilakukan untuk menjalin kerjasama antara perusahaan itu;

b. Customer to Customer, merupakan transaksi jual beli yang terjadi antara individu dengan individu yang akan saling menjual barang;

c. Customer to Business, merupakan transaksi jual beli yang terjadi antara individu sebagai penjual dengan sebuah perusahaan sebagai pembelinya;

d. Customer to Government, merupakan transaksi jual beli yang dilakukan antara individu dengan pemerintah, misalnya dalam pembayaran pajak.

Lahirnya UU ITE merupakan sebuah dilema, dan masih banyak kekurangan dalam memberikan kepastian hukum jual beli melalui internet, karena kemajuan teknologi dan industri yang semakin pesat, mau tidak mau berdampak juga bagi negara kita khususnya transaksi elektronik, dengan adanya e-banking, e-commerce, dan transaksi elektronik lainnya.

Dengan semakin banyaknya transaksi elektronik yang dilakukan, maka mendorong juga diperlukannya ketentuan hukum yang 
mengatur mengenai hal tersebut, sehingga para pihak yang terlibat dalam transaksi elektronik, khususnya konsumen mendapatkan perlindungan hukum atas setiap transaksi elektronik yang dilakukannya. Demikian juga halnya dengan data/dokumen yang dibuat secara elektronik (paperless document) juga membutuhkan adanya kekuatan hukum yang pasti, mengingat selama ini, dokumen/akta, baru dianggap sah apabila ditulis diatas kertas (hitam di atas putih). Dalam mengatasi permasalahan di atas, maka ketentuan hukum yang termuat dalam KUH Perdata masih dapat diterapkan atas transaksi jual beli secara elektronik antara lain, Pasal 1457 KUH Perdata disebutkan bahwa "Jual-beli adalah suatu persetujuan dengan mana pihak yang satu mengikatkan dirinya untuk menyerahkan suatu kebendaan dan pihak yang satu lain untuk membayar harga yang telah dijanjikan?

Dalam hukum perdata nasional Indonesia, syarat sahnya perjanjian diatur dalam Pasal 1320 KUH Perdata, yang berisi 4 (empat) syarat, yaitu adanya kesepakatan antara mereka yang mengikatkan diri, kecakapan para pihak untuk membuat suatu perikatan, suatu obyek tertentu (obyek perjanjian harus jelas dan dapat dilaksanakan) dan suatu kausa yang diperbolehkan (tidak melanggar hukum, kesusilaan dan ketertiban umum). Keempat syarat sahnya perjanjian ini otomatis juga berlaku dalam perjanjian jual beli dalam transaksi elektronik. Hal ini tegas disebutkan

\footnotetext{
${ }^{9}$ https://jurnalhukumargumentum.wordpress.com /2013/06/30/vol-12-no-2-juni-2013-slametbudiharjol, di akses pada tanggal 7 september 2016, jam 16.30 WIB
}

dalam Pasal 47 Peraturan Pemerintah Nomor 82 Tahun 2012 tentang Penyelenggaraan Sistem dan Transaksi Elektronik yang isinya sebagai berikut ${ }^{10}$ :

(1) Transaksi Elektronik dapat dilakukan berdasarkan Kontrak Elektronik atau bentuk kontraktual lainnya sebagai bentuk kesepakatan yang dilakukan oleh para pihak.

(2) Kontrak Elektronik dianggap sah apabila:

a. terdapat kesepakatan para pihak;

b. dilakukan oleh subjek hukum yang cakap atau yang berwenang mewakili sesuai dengan ketentuan peraturan perundang-undangan;

c. terdapat hal tertentu; dan

d. Objek transaksi tidak boleh bertentangan dengan peraturan perundang-undangan, kesusilaan, dan ketertiban umum.

Selain itu terdapat beberapa persyaratan tambahan dalam Pasal 48 Peraturan Pemerintah Nomor 82 Tahun 2012 tentang Penyelenggaraan Sistem dan Transaksi Elektronik sebagai berikut:

(1) Kontrak Elektronik dan bentuk kontraktual lainnya sebagaimana dimaksud dalam Pasal 47 ayat (1) yang ditujukan kepada penduduk Indonesia harus dibuat dalam Bahasa Indonesia.

(2) Kontrak Elektronik yang dibuat dengan klausula baku harus sesuai dengan ketentuan mengenai klausula baku sebagaimana diatur dalam peraturan perundang-undangan.

\footnotetext{
10 Indonesia, Peraturan Pemerintah Nomor 82 Tahun 2012 tentang Penyelenggaraan Sistem dan Transaksi Elektronik, Pasal 47.
} 
(3) Kontrak Elektronik paling sedikit memuat:

a. data identitas para pihak;

b. objek dan spesifikasi;

c. persyaratan Transaksi Elektronik;

d. harga dan biaya;

e. prosedur dalam hal terdapat pembatalan oleh para pihak;

f. ketentuan yang memberikan hak kepada pihak yang dirugikan untuk dapat mengembalikan barang dan/atau meminta penggantian produk jika terdapat cacat tersembunyi; dan

g. Pilihan hukum penyelesaian Transaksi Elektronik.

Penentuan kecakapan seseorang dalam membuat transaksi elektronik mungkin akan menjadi kendala karena para pihak tidak bertemu secara langsung. Untuk itu, sebaiknya pelaku usaha memberikan batasan umur bagi konsumen untuk dapat melakukan transaksi elektronik. Bagaimanapun, apabila syarat kecakapan ini dilanggar dan suatu saat ada pihak yang merasa dirugikan, maka pihak yang dirugikan tersebut dapat meminta agar perjanjian dibatalkan ${ }^{11}$. Selain itu, penting untuk memastikan bahwa tanda tangan elektronik di suatu kontrak/perjanjian jual beli elektronik telah memenuhi syaratsyarat yang ditetapkan untuk memastikan legalitas/ keabsahannya. Menurut Pasal 1 ayat (19) Peraturan Pemerintah Nomor 82

\footnotetext{
${ }^{11}$ Jika kesepakatan tidak diberikan secara bebas atau salah satu pihak tidak cakap untuk membuat perjanjian, maka perjanjian ini cacat sehingga dapat dibatalkan oleh hakim atas permintaan pihak yang telah memberikan kesepakatannya secara tidak bebas atau tidak cakap untuk membuat perjanjian itu. Lihat di: Subekti, Pokok-Pokok Hukum Perdata, Cetakan XXXIII, Jakarta : Intermasa, 2008, hlm. 136.
}

Tahun 2012 tentang Penyelenggaraan Sistem dan Transaksi Elektronik :

"Tanda Tangan Elektronik adalah tanda
tangan yang terdiri atas Informasi
Elektronik yang dilekatkan, terasosiasi atau
terkait dengan Informasi Elektronik lainnya
yang digunakan sebagai alat verifikasi dan
autentikasi","

Informasi Elektronik dan/atau Dokumen Elektronik dan/atau hasil cetaknya (yang berisi tanda tangan elektronik) dapat menjadi alat bukti hukum yang sah dan merupakan perluasan dari alat bukti yang telah ada menurut Hukum Acara yang berlaku di Indonesia, namun hanya apabila Informasi Elektronik dan/atau Dokumen Elektronik tersebut menggunakan Sistem Elektronik yang sesuai dengan ketentuan yang diatur dalam Undang-Undang No. 11 Tahun 2008 tentang ITE dan Peraturan Pemerintah Nomor 82 Tahun 2012 tentang Penyelenggaraan Sistem dan Transaksi Elektronik.

Diundangkannya Undang-undang Nomor 11 Tahun 2008 tentang Informasi dan Transaksi Elektronik (selanjutnya disebut dengan UU ITE) adalah wujud konkrit dari Pemerintah Indonesia untuk

12 Tanda Tangan Elektronik meliputi Tanda Tangan Elektronik tersertifikasi dan Tanda Tangan Elektronik tidak tersertifikasi. Tanda Tangan Elektronik tersertifikasi dihasilkan oleh penyelenggara sertifikasi elektronik yang dibuktikan dengan Sertifikat Elektronik. Untuk penyelenggara sertifikasi elektronik yang beroperasi di Indonesia wajib memperoleh pengakuan dari Menteri yang terdiri atas tingkatan terdaftar, tersertifikasi, atau berinduk. Kewajiban penyelenggara sertifikasi elektronik antara lain melakukan pendaftaran dan pemeriksaan calon pemilik dan/atau pemegang Sertifikat Elektronik dan menerbitkan Sertifikat Elektronik. Lihat di: Penjelasan Umum PP PSTE. 
proaktif dan responsif dalam pembangunan nasional sebagai suatu proses yang berkelanjutan dan harus senantiasa tanggap terhadap berbagai dinamika yang terjadi di masyarakat; khususnya untuk mengisi kekosongan hukum pada permasalahan perkembangan dan kemajuan teknologi informasi.

Berdasarkan Pasal 15 Undang-Undang No. 11 Tahun 2008 Tentang Informasi dan Transaksi Elektronik yaitu:

(1) Setiap Penyelenggara Sistem Elektronik harus menyelenggarakan Sistem Elektronik secara andal dan aman serta bertanggung jawab terhadap beroperasinya Sistem Elektronik sebagaimana mestinya.

(2) Penyelenggara Sistem Elektronik bertanggung jawab terhadap Penyelenggaraan Sistem Elektroniknya.

(3) Ketentuan sebagaimana dimaksud pada ayat (2) tidak berlaku dalam hal dapat dibuktikan terjadinya keadaan memaksa, kesalahan, dan/atau kelalaian pihak pengguna Sistem Elektronik.

Dari Pasal 15 ayat (2) dan ayat (3) tersebut,menunjukkan bahwa Penyelenggara Sistem Elektronik bertanggung jawab terhadap Penyelenggaraan Sistem Elektroniknya kecuali terjadi keadaan memaksa, kesalahan, dan/atau kelalaian pihak pengguna Sistem Elektronik. UndangUndang Informasi dan Transaksi Elektronik (UU ITE) memiliki asas diantaranya netral teknologi atau kebebasan memilih teknologi. Hal ini termasuk memilih jenis tanda tangan elektronik yang dipergunakan untuk menandatangani suatu informasi elektronik dan/atau dokumen elektronik. Asas netral teknologi dalam UU ITE perlu dipahami secara berhati-hati, dan para pihak yang melakukan transaksi elektronik sepatutnya menggunakan tanda tangan elektronik yang memiliki kekuatan hukum dan akibat hukum yang sah seperti diatur dalam Pasal 11 ayat 1 UU ITE. Tanda Tangan Elektronik memiliki kekuatan hukum dan akibat hukum yang sah selama memenuhi persyaratan sebagai berikut : Data pembuatan Tanda Tangan Elektronik terkait hanya kepada Penanda Tangan; Data pembuatan Tanda Tangan Elektronik pada saat proses penandatanganan Elektronik hanya berada dalam kuasa Penanda Tangan, Segala perubahan terhadap Tanda Tangan Elektronik yang terjadi setelah waktu penandatanganan dapat diketahui, Segala perubahan terhadap Informasi Elektronik yang terkait dengan Tanda Tangan.

Elektronik tersebut setelah waktu penandatanganan dapat diketahui, Terdapat cara tertentu yang dipakai untuk mengidentifikasi siapa Penandatangan nya,dan terdapat cara tertentu untuk menunjukkan bahwa Penanda Tangan telah memberikan persetujuan terhada Informasi Elektronik yang terkait.Namun demikian kemunculan UU ITE, secara substansial belum secara tegas memberikan pengaturan mengenai keabsahan atau syarat sahnya kontrak elektronik. Tidak dijelaskan secara tegas pula keterkaitan UU ITE dengan Pasal 1320 KUHPerdata seperti dikatakan oleh Huala Adolf bahwa "...mengingat ketentuan pada KUHPerdata adalah undang-undang yang dijadikan dasar dalam menentukan sah atau tidaknya sebuah perikatan khususnya jika perikatan tersebut dilakukan baik 
antara para pihak yang berdomisili di Indonesia maupun para pihak yang tunduk dengan KUHPerdata, terlebih dalam UU ITE tidak merumuskan dengan jelas bagaimana posisi keterkaitan dengan Pasal 1320 KUHPerdata dan kurangnya infra struktur hukum yang mengaturnya tidak ada"13.

Seperti yang telah disebutkan sebelumnya bahwa di Indonesia segala hal yang berkaitan dengan perikatan haruslah sesuai dengan apa yang termuat dalam Pasal 1320 KUHPerdata, sedangkan prinsip utama dari UNCITRAL melalui konvensinya adalah prinsip otonomi para pihak sebagaimana tercantum dalam Pasal 3 UNCITRAL Model Law on Electronic Commerce bahwa para pihak bebas untuk tidak menggunakan aturan substansi konvensi, termasuk di dalamnya adalah kebebasan para pihak untuk membuat peraturan berbeda dalam peraturan nasionalnya. Konvensi tidak menekankan suatu persyaratan formil tertentu untuk keabsahan suatu kontrak, hanya saja untuk menjawab kemungkinan adanya persyaratan formal tertentu yang diharuskan oleh negara anggota konvensi, maka syarat formil tersebut adalah syarat kontrak harus tertulis, syarat harus ada tandatangan, dan bentuk asli kontrak ${ }^{14}$.

Contoh pembelian melalui $E$ Commerce dapat kita lihat dalam situs www.kaskus.co.iddimana pihak pembeli (buyer) mengakses internet ke website yang kemudian pihak pembeli (buyer) mencari

\footnotetext{
${ }^{13}$ Ibid., hal. 47.

${ }^{14}$ Ibid., hal. 45.
}

barang yang diinginkan, ${ }^{15}$ Contoh kasus pada Keabsahan Transaksi Jual Beli Melalui Blackberry Messenger Perkembangan teknologi memang luar biasa, hingga bisnis pun bisa dilakukan di mana saja termasuk perkembangan smartphone yang dimiliki sekarang yaitu blackberry. Tidak hanya shop online di internet tetapi juga menjamur di bbm group yang banyak menawarkan produk-produk yang mau dijual dengan gambar dan teks. Jual beli produk (barang/jasa) yang dilakukan melalui media komunikasi Blackberry Messenger ("BBM") dimungkinkan untuk dilakukan karena memang sampai saat ini tidak ada larangan akan hal tersebut di Indonesia. Adanya pemikiran/pertimbangan untuk melarang penggunaan BBM di Indonesia dan beberapa negara lainnya seperti Cina, Arab Saudi, India, lebih karena isi komunikasi BBM tidak dapat dimonitor atau disadap oleh pemerintah/penegak hukum terkait sehingga layanan BBM ini dapat disalahgunakan untuk aktivitas yang mengancam kepentingan nasional (seperti mengorganisasi kegiatan teroris atau kerusuhan).

Pada prinsipnya (dengan beberapa pengecualian seperti pada Pasal 5 ayat (4) Undang-Undang Nomor 11 Tahun 2008 tentang Informasi dan Transaksi ElektronikUU ITE), penggunaan media komunikasi BBM atau suatu media elektronik lainnya untuk transaksi jual beli produk diserahkan kepada kebebasanpara pihak untuk menentukannya (tergantung dari

\footnotetext{
${ }^{15}$ http://e-journal.uajy.ac.id/7996/2/HK110300.pdf, di akses pada tanggal 7 September 2016, pukul 18.30 WIB
} 
kesepakatan antara penjual dan pembeli). Pasal 19 UU ITEmenyebutkan bahwa:

"Para pihak yang melakukan Transaksi Elektronik harus menggunakan Sistem Elektronik yang disepakati."

Kecuali untuk surat yang menurut Undang-Undang harus dibuat dalam bentuk tertulis, dan surat beserta dokumennya yang menurut Undang-Undang harus dibuat dalam bentuk akta notaril atau akta yang dibuat oleh pejabat pembuat akta maka transaksinyatidak sahjika dilakukan secara elektronik (Pasal 5 ayat (4) UU ITE). Contohnya, transaksi jual beli tanah yang perjanjiannya harus dibuat oleh Pejabat Pembuat Akta Tanah (PPAT).

Transaksi jual beli yang terjadi melalui layanan BBM itu sah dan mengikat para pihak sepanjang kontrak elektroniknya (perjanjian jual beli yang dibuat/dilakukan dengan cara komunikasi melalui layanan BBM) memenuhi syarat sahnya suatu perjanjian. Hal ini sesuai dengan ketentuan Pasal 1338 ayat (1) Kitab Undang-Undang Hukum Perdata ("KUHPerdata"), yang berbunyi:

"Seтиа perjanjian yang dibuatsecara sah berlaku sebagai undang-undang bagi mereka yangmembuatnya, ${ }^{16}$

${ }^{16}$ http://www.hukumonline.com/klinik/detail/lt4fec1fa 765a11/keabsahan-transaksi-jual-beli-melalui blackberry-messenger, diakses pada 7 September 2016 pukul $16.30 \mathrm{WIB}$

\section{Perlindungan Hukum Terhadap Konsumen Dalam Transaksi Jual Beli Secara Elektronik Di Indonesia.}

Dewasa ini, perkembangan perdagangan e-commerce semakin tumbuh dengan pesat. Selain membawa dampak positif bagi perkembangan dan pertumbuhan perekonomian Indonesia juga akan menimbulkan permasalahan-persamalahan yang tentunya harus ditemukan cara penyelesaiannya menggunakan peraturan perundang-undangan yang berlaku di Indonesia.

Bagi masyarakat Indonesia hal ini terkait masalah hukum yang sangat penting. Pentingnya permasalahan hukum di bidang E-Commerce adalah terutama dalam memberikan perlindungan terhadap para pihak yang melakukan transaksi melalui internet. ${ }^{17}$ Mengingat pentingnya hal tersebut maka Indonesia pada tahun 2008 lalu mengeluarkan peraturan khusus yang mengatur transaksi melalui internet yaitu Undang-Undang Nomor 11 tahun 2008 tentang Informasi dan Transaksi Elektronik yang untuk selanjutnya disingkat UU ITE. Dalam upaya menyikapi perkembangan hukum terkait dengan jual-beli melalui internet, Pemerintah telah mengeluarkan Undang-Undang Nomor 11 Tahun 2008 tentang Informasi danTransaksi Elektronik, menimbang bahwa pembangunan nasional adalah suatu proses yang berkelanjutan yang harus senantiasa tanggap terhadap berbagai dinamika yang terjadi di masyarakat. Dalam

\footnotetext{
${ }^{17}$ Lia Sautunnida, Jual Beli Melalui Internet (ECommerce) Kajian Menurut Buku III KUH Perdata dan Undang-Undang Informasi dan Transaksi Elektronik (Fakultas Hukum Universitas Syiah Kuala, 2008), hal. 1.
} 
Pasal 1 butir 2 UUITE, disebutkan bahwa transaksi elektronik adalah perbuatan hukum yang dilakukan dengan mengunakan komputer, jaringan komputer atau media elektronik lainnya. Transaksi jual beli secara elektronik merupakan salah satu perwujudan ketentuan tersebut. Kontrak elektronik dalam transaksi elektronik, harus memiliki kekuatan hukum yang sama dengan kontrak konvensional

Transaksi elektronik yang melibatkan para pihak dari dalam negeri yaitu negara Indonesia, tidaklah sulit untuk menetapkan aturan hukum yang berlaku apabila terjadi masalah. Secara otomatis the applicable law-nya adalah hukum Indonesia, sehingga baik Burgelijk Wetboek maupun UndangUndang Perlindungan Konsumen dapat diterapkan untuk menyelesaikan sengketa yang timbul. Namun bagi transaksi perdagangan lintas negarabukan Negara Indonesia, penyelesaian sengketa akan dilakukan oleh forum yang dipilih oleh para pihak dengan menggunakan hukum yang telah dipilih pula oleh para pihak dalam kontrak elektronik, sebagaimana telah dijelaskan di atas dalam pembahasan tentang pilihan hukum dan pilihan forum.

Dalam Pasal 38 Undang-Undang No. 11 Tahun 2008 tentang Informasi dan Transaksi Elektronik sendiri menegaskan bahwa "Setiap orang dapat mengajukan gugatan terhadap pihak yang menyelenggarakan Sistem Elektronik dan/atau menggunakan Teknologi Informasi yang menimbulkan kerugian”. Menurut pasal ini, masyarakat dapat mengajukan gugatan secara perwakilan terhadap pihak yang menyelenggarakan Sistem Elektronik dan/atau menggunakan Teknologi Informasi yang berakibat merugikan masyarakat, sesuai dengan ketentuan Peraturan Perundang-undangan.

Lebih lanjut Pasal 39 Undang-Undang No. 11 Tahun 2008 tentang Informasi dan Transaksi Elektronik menjelaskan bahwa "Gugatan perdata dilakukan sesuai dengan ketentuan Peraturan Perundang-undangan. Selain penyelesaian secara gugatan perdata, para pihak juga dapat menyelesaikan sengketa melalui arbitrase, atau lembaga penyelesaian sengketa alternatif lainnya sesuai dengan ketentuan Peraturan Perundang-undangan."

Hal ini sesuai dengan ketentuan dalam Pasal 23 Undang-Undang No. 8 Tahun 1999 tentang Perlindungan Konsumen yang menyatakan bahwa "Pelaku usaha yang menolak dan/atau tidak memberi tanggapan dan/atau tidak memenuhi ganti rugi atas tuntutan konsumen dapat digugat melalui badan penyelesaian sengketa konsumen atau mengajukan ke badan peradilan di tempat kedudukan konsumen." Menurut hukum yang berlaku di Indonesia, gugatan perdata dapat didasarkan atas dua alasan, yaitu wanprestasi dan perbuatan melanggar hukum (onrechtmatigedaad). Adapun landasan hukumnya didasarkan pada ketentuan Buku III pasal 1243 BW untuk wanprestasi dan pasal 1365 BW untuk perbuatan melanggar hukum.

Gugatan wanprestasi selalu berawal pada adanya suatu hubungan hukum kontraktual (perjanjian) antara para pihak, sehingga melahirkan hak dan kewajiban hukum. Hak dan kewajiban di sini diwujudkan dengan apa yang disebut sebagai prestasi (performance). Pada saat prestasi tidak dipenuhi/tidak dilaksanakan/ 
dilaksanakan tidak sebagaimana mestinya menurut perjanjian para pihak, maka lahir apa yang dinamakan wanprestasi (cidera janji). Sedangkan pada gugatan perbuatan melanggar hukum, yang menjadi dasar gugatannya adalah kepentingan pihak tertentu yang dirugikan oleh perbuatan pihak lainnya, meskipun di antara para pihak tidak terdapat suatu hubungan hukum keperdataan yang bersifat kontraktual (perjanjian).

Untuk kasus-kasus kerugian konsumen dalam transaksi perdagangan secara elektronik, gugatan akan lebih tepat bila didasarkan atas wanprestasi dan bukan perbuatan melanggar hukum, yaitu dengan merujuk pada kewajiban-kewajiban pelaku usaha dalam kontrak elektronik yang telah dilanggar dan karenanya menimbulkan kerugian. Selain penyelesaian secara perdata, pelanggaran dalam transaksi elektronik yang mengandung unsur pidana seperti penipuan juga dapat diproses secara pidana, sebagaimana yang disebutkan dalam Pasal 19 ayat (4) Undang-Undang Perlindungan Konsumen yang menyatakan bahwa "pemberian ganti rugi tidak menghapuskan kemungkinan adanya tuntutan pidana berdasarkan pembuktian lebih lanjut mengenai adanya unsur kesalahan". ${ }^{18}$

Jika kejahatan e-commerce sudah masuk pada ranah pidana maka ketentuan dalam peraturan perundang-undangan Indonesia telah mengaturnya, yakni dalam Undang-Undang No. 11 Tahun 2008 tentang

\footnotetext{
${ }^{18}$ Rosalinda Elsina Latumahina, Aspek-Aspek Hukum Dalam Transaksi Perdagangan Secara Elektronik, Jurnal GEMA AKTUALITA, Vol. 4 No. 1, Juni 2015, Fakultas Hukum Universitas Pelita Harapan Surabaya Surabaya, 2015, hal. 50-51.
}

Informasi dan Transaksi Elektronik, antara lain dalam Pasal 30 sebagai berikut :

(1) Setiap Orang dengan sengaja dan tanpa hak atau melawan hukum mengakses Komputer dan/atau Sistem Elektronik milik Orang lain dengan cara apa pun.

(2) Setiap Orang dengan sengaja dan tanpa hak atau melawan hukum mengakses Komputer dan/atau Sistem Elektronik dengan cara apa pun dengan tujuan untuk memperoleh Informasi Elektronik dan/atau Dokumen Elektronik.

(3) Setiap Orang dengan sengaja dan tanpa hak atau melawan hukum mengakses Komputer dan/atau Sistem Elektronik dengan cara apa pun dengan melanggar, menerobos, melampaui, atau menjebol sistem pengamanan.

Selanjutnya ketentuan hukumnya tercantum dalam Pasal 46 Undang-Undang No. 11 Tahun 2008 tentang Informasi dan Transaksi Elektronik adalah sebagai berikut:

(1) Setiap Orang yang memenuhi unsur sebagaimana dimaksud dalam Pasal 30 ayat (1) dipidana dengan pidana penjara paling lama 6 (enam) tahun dan/atau denda paling banyak Rp600.000.000,00 (enam ratus juta rupiah).

(2) Setiap Orang yang memenuhi unsur sebagaimana dimaksud dalam Pasal 30 ayat (2) dipidana dengan pidana penjara paling lama 7 (tujuh) tahun dan/atau denda paling banyak Rp700.000.000,00 (tujuh ratus juta rupiah). 
(3) Setiap Orang yang memenuhi unsur sebagaimana dimaksud dalam Pasal 30 ayat (3) dipidana dengan pidana penjara paling lama 8 (delapan) tahun dan/atau denda paling banyak Rp.800.000.000,00 (delapan ratus juta rupiah).

Dalam Undang-undang Perlindungan Konsumen diatur mengenai hak konsumen, Pasal 4 Undang-Undang Nomor 8 Tahun 1999 tentang Perlindungan Konsumen menyebutkan bahwa hak konsumen adalah :

a. Hak atas kenyamanan, keamanan, dan keselamatan dalam mengkonsumsi barang dan/atau jasa;

b. Hak untuk memilih barang dan/atau jasa serta mendapatkan barang dan/atau jasa tersebut sesuai dengan nilai tukar dan kondisi serta jaminan yang dijanjikan;

c. Hak atas informasi yang benar, jelas, dan jujur mengenai kondisi dan jaminan barang dan/atau jasa;

d. Hak untuk didengar pendapat dan keluhannya atas barang dan/atau jasa yang digunakan;

e. Hak untuk mendapatkan advokasi, perlindungan, dan upaya penyelesaian sengketa perlindungan konsumen secara patut;

f. Hak untuk mendapat pembinaan dan pendidikan konsumen;

g. Hak unduk diperlakukan atau dilayani secara benar dan jujur serta tidak diskriminatif;

h. Hak untuk mendapatkan kompensasi, ganti rugi dan/atau penggantian, apabila barang dan/atau jasa yang diterima tidak sesuai dengan perjanjian atau tidak sebagaimana mestinya;

i. Hak-hak yang diatur dalam ketentuan peraturan perundangundangan lainnya.

Di sisi lain, kewajiban bagi pelaku usaha (dalam hal ini adalah penjual online), sesuai Pasal 7 Undang-Undang Nomor 8 Tahun 1999 tentang Perlindungan Konsumen adalah:

a. Beritikad baik dalam melakukan kegiatan usahanya;

b. Memberikan informasi yang benar, jelas dan jujur mengenai kondisi dan jaminan barang dan/atau jasa serta memberi penjelasan penggunaan, perbaikan dan pemeliharaan;

c. Memperlakukan atau melayani konsumen secara benar dan jujur serta tidak diskriminatif;

d. Menjamin mutu barang dan/atau jasa yang diproduksi dan/atau diperdagangkan berdasarkan ketentuan standar mutu barang dan/atau jasa yang berlaku;

e. Memberi kesempatan kepada konsumen untuk menguji, dan/atau mencoba barang dan/atau jasa tertentu serta memberi jaminan dan/atau garansi atas barang yang dibuat dan/atau yang diperdagangkan;

f. Memberi kompensasi, ganti rugi dan/atau penggantian atas kerugian akibat penggunaan, pemakaian dan pemanfaatan barang dan/atau jasa yang diperdagangkan;

g. Memberi kompensasi, ganti rugi dan/atau penggantian apabila barang dan/atau jasa yang diterima 
atau dimanfaatkan tidak sesuai dengan perjanjian.

Terkait dengan persoalan yang Anda tanyakan, lebih tegas lagi Pasal 8 UndangUndang Nomor 8 Tahun 1999 tentang Perlindungan Konsumen melarang pelaku usaha untuk memperdagangkan barang/jasa yang tidak sesuai dengan janji yang dinyatakan dalam label, etiket, keterangan, iklan atau promosi penjualan barang dan/atau jasa tersebut. Berdasarkan pasal tersebut, ketidaksesuaian spesifikasi barang yang Anda terima dengan barang tertera dalam iklan/foto penawaran barang merupakan bentuk pelanggaran / larangan bagi pelaku usaha dalam memperdagangkan barang. Anda selaku konsumen sesuai Pasal 4 huruf h UndangUndang Nomor 8 Tahun 1999 tentang Perlindungan Konsumen tersebut berhak mendapatkan kompensasi, ganti rugi dan/atau penggantian apabila barang dan/atau jasa yang diterima tidak sesuai dengan perjanjian atau tidak sebagaimana mestinya. Sedangkan, pelaku usaha itu sendiri sesuaiPasal 7 huruf g UUPK berkewajiban memberi kompensasi, ganti rugi dan/atau penggantian apabila barang dan/atau jasa yang diterima atau dimanfaatkan tidak sesuai dengan perjanjian. Apabila pelaku usaha tidak melaksanakan kewajibannya, pelaku usaha dapat dipidana berdasarkan Pasal 62 Undang-Undang Nomor 8 Tahun 1999 tentang Perlindungan Konsumen, yang berbunyi :

Pelaku usaha yang melanggar ketentuan sebagaimana dimaksud dalam Pasal 8, Pasal 9, Pasal 10, Pasal 13 ayat (2), Pasal 15, Pasal 17 ayat (1) huruf a, huruf b, huruf c, huruf e, ayat (2) dan Pasal 18 dipidana dengan pidana penjara paling lama 5 (lima) tahun atau pidana denda paling banyak Rp 2.000.000.000,00 (dua milyar rupiah).

Kontrak Elektronik dan Perlindungan Konsumen berdasarkan UU ITE dan PP PSTE Transaksi jual beli Anda, meskipun dilakukan secara online, berdasarkan UU ITE dan PP PSTE tetap diakui sebagai transaksi elektronik yang dapat dipertanggungjawabkan. Persetujuan Anda untuk membeli barang secara online dengan cara melakukan klik persetujuan atas transaksi merupakan bentuk tindakan penerimaan yang menyatakan persetujuan dalam kesepakatan pada transaksi elektronik. Tindakan penerimaan tersebut biasanya didahului pernyataan persetujuan atas syarat dan ketentuan jual beli secara online yang dapat kami katakan juga sebagai salah satu bentuk Kontrak Elektronik. Kontrak Elektronik menurut Pasal 47 ayat (2) PP PSTE dianggap sah apabila:

a. Terdapat kesepakatan para pihak;

b. Dilakukan oleh subjek hukum yang cakap atau yang berwenang mewakili sesuai dengan ketentuan peraturan perundang-undangan;

c. Terdapat hal tertentu; dan

d. Objek transaksi tidak boleh bertentangan dengan peraturan perundang-undangan, kesusilaan, dan ketertiban umum.

Kontrak Elektronik itu sendiri menurut Pasal 48 ayat (3) PP PSTE setidaknya harus memuat hal-hal sebagai berikut:

a. Data identitas para pihak;

b. Objek dan spesifikasi; 
c. Persyaratan Transaksi Elektronik;

d. Harga dan biaya;

e. Prosedur dalam hal terdapat pembatalan oleh para pihak;

f. Ketentuan yang memberikan hak kepada pihak yang dirugikan untuk dapat mengembalikan barang dan/atau meminta penggantian produk jika terdapat cacat tersembunyi; dan

g. Pilihan hukum penyelesaian Transaksi Elektronik.

Dengan demikian, pada transaksi elektronik yang Anda lakukan, Anda dapat menggunakan instrumen UU ITE dan/atau PP PSTE sebagai dasar hukum dalam menyelesaikan permasalahan Anda.Terkait dengan perlindungan konsumen, Pasal 49 ayat (1) PP PSTE menegaskan bahwa Pelaku Usaha yang menawarkan produk melalui Sistem Elektronik wajib menyediakan informasi yang lengkap dan benar berkaitan dengan syarat kontrak, produsen, dan produk yang ditawarkan. Pada ayat berikutnya lebih ditegaskan lagi bahwa Pelaku Usaha wajib memberikan kejelasan informasi tentang penawaran

kontrak atau iklan.

Berdasarkan Pasal 49 ayat (3) PP PSTE mengatur khusus tentang hal tersebut, yakni Pelaku Usaha wajib memberikan batas waktu kepada konsumen untuk mengembalikan barang yang dikirim apabila tidak sesuai dengan perjanjian atau terdapat cacat tersembunyi.Selain kedua ketentuan tersebut di atas, apabila ternyata barang yang Anda terima tidak sesuai dengan foto pada iklan toko online tersebut (sebagai bentuk penawaran), Anda juga dapat menggugat Pelaku Usaha (dalam hal ini adalah penjual) secara perdata dengan dalih terjadinya wanpretasi atas transaksi jual beli yang Anda lakukan dengan penjual. Menurut Prof. R. Subekti, S.H. dalam bukunya tentang "Hukum Perjanjian" , wanprestasi adalah kelalaian atau kealpaan yang dapat berupa 4 macam kondisi yaitu:

a. Tidak melakukan apa yang disanggupi akan dilakukannya;

b. Melaksanakan apa yang dijanjikannya, tetapi tidak sebagaimana dijanjikan;

c. Melakukan apa yang dijanjikannya tetapi terlambat;

d. Melakukan sesuatu yang menurut perjanjian tidak boleh dilakukannya.

Jika salah satu dari 4 macam kondisi tersebut terjadi, maka Anda secara perdata dapat menggugat penjual online dengan dalih terjadi wanprestasi (misalnya, barang yang Anda terima tidak sesuai dengan spesifikasi barang yang dimuat dalam display home page/web site). Pidana Penipuan dalam Transaksi Jual Beli Secara Online, Hal yang perlu diingat adalah bahwa jual beli secara online pada prinsipnya adalah sama dengan jual beli secara faktual pada umumnya. Hukum perlindungan konsumen terkait transaksi jual beli online pun sebagaimana kami jelaskan sebelumnya tidak berbeda dengan hukum yang berlaku dalam transaksi jual beli secara nyata. Pembedanya hanya pada penggunaan sarana internet atau sarana telekomunikasi lainnya. Akibatnya adalah dalam transaksi jual beli secara online sulit dilakukan eksekusi ataupun tindakan nyata apabila terjadi sengketa maupun tindak pidana penipuan. Sifat siber dalam transaksi secara elektronis memungkinkan setiap orang baik penjual maupun pembeli menyamarkan atau 
memalsukan identitas dalam setiap transaksi maupun perjanjian jual beli.

Dalam hal pelaku usaha atau penjual ternyata menggunakan identitas palsu atau melakukan tipu muslihat dalam jual beli online tersebut, maka pelaku usaha dapat juga dipidana berdasarkan Pasal 378 Kitab Undang-Undang Hukum Pidana ("KUHP") tentang penipuan dan Pasal 28 ayat (1) UU ITEtentang menyebarkan berita bohong dan menyesatkan yang mengakibatkan kerugian konsumen dalam Transaksi Elektronik.

Bunyi selengkapnya Pasal 378 KUHP adalah sebagai berikut:

\begin{abstract}
"Barangsiapa dengan maksud untuk menguntungkan diri sendiri atau orang lain secara melawan hukum, dengan memakai nama palsu atau martabat palsu, dengan tipu muslihat, ataupun rangkaian kebohongan, menggerakkan orang lain untuk menyerahkan barang sesuatu kepadanya, atau supaya memberi hutang maupun menghapuskan piutang, diancam karena penipuan dengan pidana penjara paling lama empat tahun".
\end{abstract}

Bunyi selengkapnya Pasal 28 ayat (1) UU ITE adalah sebagai berikut:

"Setiap orang dengan sengaja, dan tanpa hak menyebarkan berita bohong dan menyesatkan yang mengakibatkan kerugian konsumen dalam Transaksi Elektronik."

Perbuatan sebagaimana dijelaskan di dalam Pasal 28 ayat (1) UU ITE diancam dengan pidana penjara paling lama 6 (enam) tahun dan/atau denda paling banyak Rp. 1 miliar (Pasal 45 ayat [2] UU ITE).Berdasarkan hal-hal tersebut diatas, penyelesaian sengketa dalam transaksi perdagangan secara elektronik dapat dilakukan secara perdata maupun pidana, sehinga memberikan payung hukum kepada masayarakat di Indonesia.

Contoh kasus yang pernah terjadi di Sleman, salah satu konsumen transaksi elektronik pernah tertipu oleh bisnis jual beli on lineini. Agung, seorang mahasiswa Universitas Atma Jaya Yogyakarta yang tinggal di Desa Pandowoharjo,Kecamatan Sleman, Kabupaten Sleman, DIY, juga pernah mengalami kasus penipuan dalam transaksi elektronik. Saudara Agung merupakan konsumen online shop, membeli sebuah handphonebermerek Blackberry, melalui situs kaskus.com. informasi yang disampaikan dalam situs ini menyebutkan bahwa blackberry yang dijual adalah jenis Onyx 2 seharga Rp. 1.300.000,- dengan menampilkan contoh barang yang dijual. Semua berjalan sesuai prosedur, Agung menyepakati barang yang dibeli, memberitahu alamat detail pengiriman, membayar sesuai kesepakatan yaitu Rp. 1.300.000, serta memberikan konfirmasi kepada pihak online shop bahwa telah melakukan pembayaran dengan menunjukkan bukti foto kuitansi ATM. Namun pihak pelaku usaha tidak bersedia mengirimkan barang dengan alasan pihak pelaku usaha akan mengirimkan barang apabila Agung sebagai konsumen membeli barang tersebut 2 buah. Padahal kesepakatan awal Agung akan membeli sebuah Blackberry, namun setelah proses pembayaran terjadi, pihak pelaku usaha mengelak untuk mengirimkan barangnya. 
Adanya kesalahan informasi dari pelaku usaha online shopini membuat Agung mengalami kerugian. Untuk memperjuangkan haknya, Agung berusaha menelepon pelaku usaha meminta uangnya dikembalikan, namun ternyata nomor telepon si penjual sudah tidak aktif lagi. Setelah kejadian ini Agung memilih untuk pasrah tanpa melaporkan kejadian yang menimpanya ke pihak yang berwenang.

Dalam UUPK pasal 4 huruf (e) diatur mengenai hak konsumen yaitu hak untuk mendapatkan advokasi, perlindungan, dan upaya penyelesaian sengketa perlindungan konsumen secara patut. Namun dalam kasus di atas, Agung sebagai konsumen tidak menggunakan haknya dengan sebagaimana mestinya. Pasal 45 ayat (1) Undang-Undang ini juga menyebutkan bahwa setiap konsumen yang dirugikan dapat menggugat pelaku usaha melalui lembaga yang bertugas menyelesaikan sengketa antara konsumen dan pelaku usaha atau melalui peradilan yang berada di lingkungan peradilan umum. Bahwa secara jelas telah diatur di dalam Undang-Undang mengenai hak konsumen yang melekat pada Agung serta mereka juga bisa menggugat pelaku usaha yang merugikan mereka ${ }^{19}$.

\section{Penutup}

\section{Kesimpulan}

Dari pembahasan tersebut diatas, maka dapat disimpulkan sebagai berikut :

a. Keabsahan Perjanjian Jual Beli Secara Elektronik, Undang-Undang Informasi dan Transaksi Elektronik

\footnotetext{
${ }^{19}$ http://e-journal.uajy.ac.id/6633/2/HK110085.pdf, di
} akses pada tanggal 7 September, Pukul 19.30 WIB
(UU ITE) memiliki asas diantaranya netral teknologi atau kebebasan memilih teknologi. Hal ini termasuk memilih jenis tanda tangan elektronik yang dipergunakan untuk menandatangani suatu informasi elektronik dan/atau dokumen elektronik. Asas netral teknologi dalam UU ITE perlu dipahami secara berhati-hati, dan para pihak yang melakukan transaksi elektronik sepatutnya menggunakan tanda tangan elektronik yang memiliki kekuatan hukum dan akibat hukum yang sah seperti diatur dalam Pasal 11 ayat 1 UU ITE. Tanda Tangan Elektronik memiliki kekuatan hukum dan akibat hukum yang sah selama memenuhi persyaratan sebagai berikut : Data pembuatan Tanda Tangan Elektronik terkait hanya kepada Penanda Tangan; Data pembuatan Tanda Tangan Elektronik pada saat proses penandatanganan Elektronik hanya berada dalam kuasa Penanda Tangan, Segala perubahan terhadap Tanda Tangan Elektronik yang terjadi setelah waktu penandatanganan dapat diketahui, Segala perubahan terhadap Informasi Elektronik yang terkait dengan Tanda Tangan

b. Perlindungan Hukum Terhadap Konsumen Dalam Transaksi Jual Beli Secara Elektronik, dapat dilakukan dengan cara mengajukan gugatan wanprestasi, dengan alasan hokum tidak terpenuhinya kewajibankewajiban pelaku usaha dalam kontrak elektronik. Tidak 
terpenuhinya kewajiban ini berarti telah terjadi pelanggaran hak bagi pihak lain (pembeli) dan akibat hukumnya adalah menimbulkan kerugian. Perlindungan hokum didasarkan padaPasal 38 danPasal 39 Undang-Undang No. 11 Tahun 2008 tentang Informasi dan Transaksi Elektronik dan Pasal 23 UndangUndang No. 8 Tahun 1999 tentang Perlindungan Konsumen. Regulasi ini memberikan paying hukum terhadap orang-orang yang merasa dirugikan terhadap kegiatan ecommerce. Pengesahan UU ITE pada tahun 2008 merupakan bentuk dari keseriusan Indonesia untuk memberikan kepastian hukum kepada masyarakat terkait dengan sengketasengketa yang terjadi melalui media teknologi informasi, yang bermuara pada pencapaian nilai keadilan dan kemanfaatan.

\section{Implikasi}

a. Asas netral teknologi atau kebebasan memilih teknologi, harus dipahami sebagai langkah awal sebelum melakukan e-commerce. Keabsahan sebenarnya didasarkan adanya perjanjian yang dilakukan para pihak. Tetapi masyarakat belum semuanya dapat memahami, maka perlu adanya sosialisasi, terutama terkait dengan fungsi dan makna tanda tangan elektronik

b. Regulasi yang dijadikan paying hokum adalahPasal 38 danPasal 39 Undang-Undang No. 11 Tahun 2008 tentang Informasi dan Transaksi
ElektronikdanPasal 23 UndangUndang No. 8 Tahun 1999 tentang Perlindungan Konsumen. Pada taraf imlementasi / pelaksanaannya perluadanya fungsi contoling dan evaluasi secara berkala oleh badan yang berwenang dan masyarkat, terutama untuk memberikan keadilan pada sengketa yang muncul akibat wanprestasi.

\section{Saran}

Berdasarkan kesimpulan di atas maka dapat diajukan rekomendasi sebagai berikut

a. Untuk mengantisipasi semakin berkembangnya transaksi komersial elektronik (e-commerce) dan untuk menjamin kepastian hukum dalam transaksi komersial elektronik (ecommerce) hendaknya Indonesia segera membentuk/mengesahkan peraturan/hukum yang mengatur mengenai hal inidanIndonesia sebaiknya melakukan kerjasama dengan negara-negara lain mengingat bahwa transaksi komersial elektronik (e-commerce) bersifat borderless (tidak mengenal batas geografis).

b. Melakukan sosialisasi mengenai transaksi komersial elektronik (ecommerce) kepada masyarakat dan para penegak hukum agar masyarakat dan para penegak hukum memahami mekanisme dan permasalahan yang berkaitan dengan transaksi komersial elektronik (e-commerce)dan menyiapkan infrastruktur dan sumber daya manusia yang baik untuk mendukung perkembangan transaksi 
Jurnal Unifikasi, ISSN 2354-5976

Vol. 3 No. 2 Juli 2016

$$
\begin{aligned}
& \text { komersial elektronik (e-commerce) di } \\
& \text { Indonesia maupun cara dan } \\
& \text { bagaimaan penyelesaiannya baik } \\
& \text { melalui pengadilan untuk } \\
& \text { penyelesaian sengketa yang terjadi } \\
& \text { akibat meningkatnya transaksi } \\
& \text { elektonik di Indonesia. } \\
& \text { c. Membentuk Komisi Pengawas } \\
& \text { perdagangan on-line, dengan } \\
& \text { memberikan kewenangan untuk } \\
& \text { mengawasi perizinan perdagangan } \\
& \text { online, yang bertanggungjawab } \\
& \text { kepada pemerintah. }
\end{aligned}
$$

d. Revitalisasi fungsi Lembaga perlindungan konsumen di Indonesia sebagai mitra Komisi Pengawas Perdagangan online, pelanggaran di bidang e-commerce dapat diminimalisasi, guna mencapai keadilan, kepastian hokum dan kemanfaatan, sehingga tercapai kesejahteraan bagi seluruh lapisan masyarakat.

\section{DAFTAR PUSTAKA}

\section{Buku}

Adolf, Huala. Dasar-Dasar Hukum Kontrak Internasional, Bandung : Refika Aditama, 2007.

Badrulzaman, Mariam Darus. Kontrak Dagang Elektronik Tinjauan Dari Aspek Hukum Perdata, Dalam Kompilasi Hukum Perikatan, Bandung : Citra Aditya Bakti, 2001.

Hardjowahono,Bayu Setyo. Dasar-dasar Hukum Perdata Internasional, Buku I, Bandung :Citra Aditya Bakti,2006.

Kwary, Deny Arnos dkk. dengan judul Pengantar Teknologi Informasi, Jakarta : Salemba Infotek, 2006.

Mansur, Dikdik M. Arief dan Elisatris Gultom, Cyberlaw: Aspek Hukum Teknologi Informasi, Cetakan I, Bandung : PT. Refika Aditama, 2005.

Rahman, Hasanuddin. Contract Drafting Seri Ketrampilan Merancang Kontrak Bisnis, Bandung : Citra Aditya Bakti, 2003.

Sastrawidjaja, Man Suparman.Perjanjian Baku Dalam Aktivitas Dunia Maya, Cyberlaw: Suatu Pengantar, Cetakan I, Jakarta : Elips II, 2002.

Sitompul, Asril. Hukum Internet (Pengenal Mengenai Masalah Hukum di Cyberspace), Cetakan II, Bandung : PT. Citra Aditya Bakti, 2004.

Subekti. Pokok-Pokok Hukum Perdata, Cetakan XXXIII, Jakarta : Intermasa, 2008.

Tanya, Bernard L. et all, Teori Hukum : Strategi Tertib Manusia Lintas Ruang dan Generasi, Yogyakarta : Genta Publishing, 2013.

\section{Peraturan Perundang-Undangan}

Indonesia. Undang-Undang No. 8 Tahun 1999 tentang Perlindungan Konsumen; . Undang-Undang No. 11 Tahun 2008 tentang Informasi dan Transaksi Elektronik. 
Jurnal Unifikasi, ISSN 2354-5976

Vol. 3 No. 2 Juli 2016

. Peraturan Pemerintah Nomor 82 Tahun 2012 tentang Penyelenggaraan Sistem dan Transaksi Elektronik.

. Peraturan Presiden Republik Indonesia Nomor 39 Tahun 2014 Tentang Daftar Bidang Usaha yang Tertutupdan Bidang Usaha yang Terbuka Dengan Persyaratan Di Bidang Penanaman Modal

\section{Lain-lain :}

Kuspraningrum, Emilda.Keabsahan Kontrak Elektronik Dalam UU ITE Ditinjau Dari Pasal 1320 KUHPerdata dan UNCITRAL Model Law On Electronic Commerce, Risalah HUKUM Fakultas Hukum Unmul Vol. 7, No. 2, Desember 2011.

Latumahina, Rosalinda Elsina. Aspek-Aspek Hukum Dalam Transaksi Perdagangan Secara Elektronik, Jurnal GEMA AKTUALITA, Vol. 4 No. 1, Juni 2015, Fakultas Hukum Universitas Pelita Harapan Surabaya Surabaya, 2015.

Marzuki, Peter Mahmud. Kontrak Bisnis Internasional, Bahan Kuliah Magister Hukum Universitas Airlangga, Surabaya, 2001, pada Emilda Kuspraningrum, Keabsahan Kontrak Elektronik Dalam UU ITE Ditinjau Dari Pasal 1320 KUHPerdata dan UNCITRAL Model Law On Electronic Commerce, Risalah HUKUM Fakultas Hukum Unmul Vol. 7, No. 2, Desember 2011.

Syahdeini,Sutan Remy.E-Commerce Tinjauan dari Presfektif Hukum, Majalah Hukum Bisnis, Vol 12, 2001.

Widjaja, Gunawan. Aspek Hukum Dalam Kontrak Dagang Internasional :Analisis yuridis Terhadap Kontrak Jual Beli Internasional, Jurnal Hukum Bisnis, Vo. 27 No. 4 Tahun 2008.

Budi Rahardjo, Peraturan dan Pengaturan Cyberspace di Indonesia, tersedia di <https://behard.files.wordpress.com/2011/01/draft-buku-cyberlaw.pdf>,diakses pada 6 Juli 2016 pukul 14.00 WIB.

Jokowi Boyong 5 Bos Perusahaan e-Commerce RI ke AS, tersedia di $<$ http://bisnis.liputan6.com/read/2347628/jokowi-boyong-5-bos-perusahaan-ecommerce-ri-ke-as>diakses pada 6 Juli 2016 pukul 14.00 WIB.

https://jurnalhukumargumentum.wordpress.com/2013/06/30/vol-12-no-2-juni-2013 slametbudiharjo/, di akses pada tanggal 7 september 2016, jam 16.30 WIB

http://www.hukumonline.com/klinik/detail/lt4fec1fa765a11/keabsahan-transaksi-jual-belimelalui blackberry-messenger, diakses pada 7 September 2016 pukul 16.30 WIB

http://e-journal.uajy.ac.id/6633/2/HK110085.pdf, diakses pada tanggal 7 September, Pukul $19.30 \mathrm{WIB}$

http://e-journal.uajy.ac.id/7996/2/HK110300.pdf, diakses pada tanggal 7 September 2016, pukul 18.30 WIB 